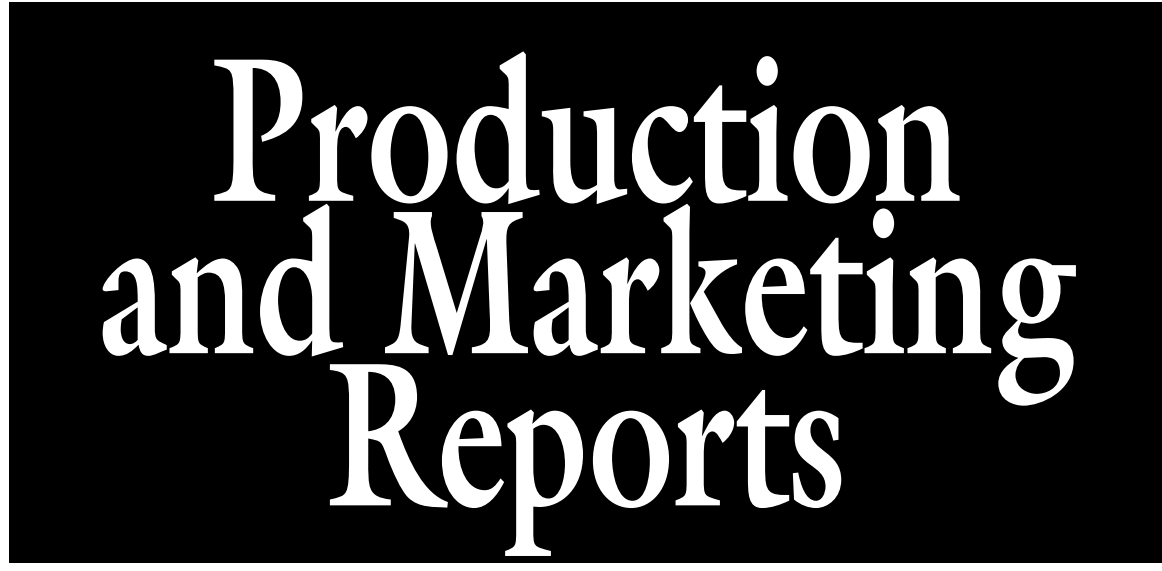

\title{
Determining Interest in Value-added Planters: Consumer Preference and Current Grower and Retailer Perceptions
}

\author{
Jonathan Phillips, E. Jay Holcomb ${ }^{1}$, and Kathleen Kelley
}

\begin{abstract}
ADDITIONAL INDEX WORDs. annual flowering plants, conjoint analysis, color, consumer research, demographics, price
\end{abstract}

Summary. Three intercept surveys were conducted at the Southeast Research and Extension Center in Landisville, Pa., at three separate field days during the period of 28 July to 4 Aug. 2004 to determine grower $(n=78)$, retailer/landscaper $(\mathbf{n}=\mathbf{5 2})$, and consumer $(\mathbf{n}=\mathbf{5 5})$ interest in annual planters. Survey participants were self-selected and asked to answer questions evaluating their preferences and past experience with annual planters. Consumer participants also evaluated planters based on flower-color harmony, container style, and price on a scale of 1 to $7(1=$ very unlikely to purchase, $7=$ very likely to purchase $)$ and answered sociographic and demographic questions. Container evaluations were analyzed using conjoint analysis to determine consumer preferences. Price was found to be the most important factor, accounting for $43.1 \%$ of the decision to purchase an annual planter. No significance was found comparing the lowest $(\$ 19.98)$ and middle ( $\$ 29.98$ ) prices; however, both were significantly more preferred than the highest price point $(\$ 39.98)$. Color harmony was the next most important factor, accounting for $34.9 \%$ of the decision to purchase followed by container style

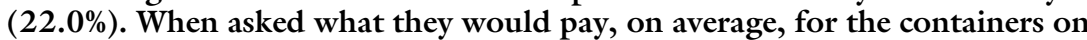
display, consumer participants responded with a price of $\$ 25.68$. A majority of retail/landscape participants in this study had never sold annual planters within their company $(75.0 \%)$, whereas a majority of grower participants had produced annual planters in the past $(\mathbf{7 5 . 0 \%})$. Retailer/landscape participants also indicated that they would charge their customers an average retail price of $\$ 31.67$, which was $14 \%$ less than the growers' suggested average retail price of $\$ 36.83$ based on the $\$ 21.68$ wholesale price they assigned.

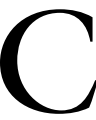

ontainer gardening is one of the most rapidly growing segments of the gardening industry (Miller, 2001). Dollar sales for container gardening have increased rapidly in the past 10 years. In only a

\footnotetext{
Department of Horticulture, The Pennsylvania State University, University Park, PA 16802

Use of trade names does not imply endorsement of the products named or criticism of similar ones not named.

${ }^{1}$ Corresponding author.

E-mail: ejh3@psu.edu
}

2-year period from 1997 to 1999 , sales increased from $\$ 558$ million annually to over $\$ 1$ billion (Butterfield, 2003). With the explosion of highdensity housing, there has been an increased interest for patio container gardens due to their many benefits (Miller, 2001), specifically their versatility and practicality. In addition, today's consumer is less interested in physically demanding projects (Miller, 2004).

Container gardens allow hobbyists to care for plants without the need for a planting bed and can allow for beautiful plantings in virtually any situation, making them ideal for use in high-density housing. Additionally, container gardens can be moved to suit the needs of the owner and individual plants can be removed, once flowering has declined, to be replaced with those ready to bloom. Container gardens also require less care than conventional in-ground gardens, making them ideal for those who may have constraints on their time, as well as the elderly, who may have problems physically maintaining a conventional garden (Jett, 2005).

Color has a great impact on human consciousness. Colors have the ability to evoke emotions or feelings in humans simply by being viewed. Red, for example, tends to be an exciting color, whereas blue tends to have a calming effect. To this extent, color is one of the most important elements of design in floral arranging because it is the first characteristic that is recognized (Hillier, 2000 ). Any combination of colors that is pleasing to the eye is given the term color harmony (Hillier, 2000).

There are five major harmonies: monochromatic, analogous, direct complement, split complement, and triad. Monochromatic combinations use the complete range of a single color, including all of the tints, shades, and tones. Analogous combinations are created using three colors that appear next to each other on the color wheel. Direct complement combinations are created using two colors that lie directly opposite each other on the color wheel, for example, yellow and violet. Direct complementary colors offset each other, making both colors appear more vivid

\begin{tabular}{llll}
\hline $\begin{array}{l}\text { Units } \\
\begin{array}{l}\text { To convert U.S. to SI, } \\
\text { multiply by }\end{array}\end{array}$ & U.S. unit & SI unit & $\begin{array}{l}\text { To convert SI to U.S., } \\
\text { multiply by }\end{array}$ \\
\hline 29.5735 & $\mathrm{fl} \mathrm{oz}$ & $\mathrm{mL}$ & 0.0338 \\
0.0929 & $\mathrm{ft}^{2}$ & $\mathrm{~m}^{2}$ & 10.7639 \\
2.5400 & inch $(\mathrm{es})$ & $\mathrm{cm}$ & 0.3937 \\
1 & $\mathrm{ppm}$ & $\mathrm{mg} \cdot \mathrm{L}^{-1}$ & 1
\end{tabular}


(Hillier, 2000). Split complement combinations use three colors: a hue and the colors on either side of the direct complement of the hue. The final major color harmony is a triad. This harmony uses three colors that are spaced equally apart on the color wheel, for example, red, blue, and yellow.

Color has been found to play the most important role in consumer purchasing decisions for many horticultural products, including edible flowers, bedding plants, and vegetables (Behe et al., 1999; Frank et al., 2001; Kelley et al., 2001; Wolnick, 1983). Because of this influence, it is necessary to carefully identify how consumers value color combinations when evaluating the purchase of valueadded floricultural products. In understanding this, retailers and growers can select and create products that best meet their customers' demands, which also offer additional timesavings benefits: consumers no longer have to search for directions or actually have to construct or "pot-up" the product.

A commodity is defined as a good that is indistinguishable from others like it, often produced in large quantities and sold inexpensively (Carlson, 2004). Value-added products are created by adding an enhancement to a good produced by a company before it is offered to the consumer, resulting in the product being more valuable than in its original state (Coltrain et al., 2000). Value-added products save the consumer time, offer the consumer a product that they may not have the knowledge to make themselves, and also distinguish a company's products from competitors' offerings.

Consumer decision to purchase a product is often based on the attributes of the product (Manalo, 1990) and market research is conducted to determine which product attributes appeal the most. Full-concept conjoint analysis is a widely accepted research technique that is used to help evaluate how important a product's attributes are to consumers (SPSS Inc., 1997). In full-concept conjoint analysis, multiple attributes of a product can be compared with each other at the same time, resulting in a more realistic method of determining consumer preference than simply asking consumers whether they like or dislike a single product attribute (SPSS, Inc., 1997). Conjoint analysis has been used effectively in the horticulture industry to determine which product attributes horticulture consumers find most important in their decision to purchase an item.

Conjoint analysis also allows the levels within an attribute to be ranked based on consumer preference. Each level within an attribute is assigned a number known as a utility in the analysis. Utilities can be either positive or negative. The more positive the value, the more preferred it is by the consumer, whereas the more negative the value, the less preferred it is by the consumer. All utility values are normal, so they will sum to zero within one attribute (SPSS, 2001).

An orthogonal design is a sample taken from the total number of combinations obtained from combining all attributes in a study. The sample is chosen in such a way that utilities can still be calculated (SPSS, 1997). Within an orthogonal design, interactions between attributes are considered to be insignificant and can, therefore, be ignored. Orthogonal designs are generated with equal representation of all attributes, that is, each attribute is combined with all other attributes the same number of times or in the same proportion (SPSS, 1997). Once utilities for attributes used within the orthogonal design are obtained, they can be used in prediction equations to estimate the utilities for attributes that were not evaluated by the participants (SPSS, 1997).

A consumer research study was conducted to 1 ) evaluate consumer preference for value-added annual planters based on color harmony, container style, and retail price; 2) understand grower and retailer interest and intent on offering annual planters similar to those evaluated by consumer participants; and 3) examine the likelihood of consumer interest in purchasing annual planters similar to those evaluated.

\section{Materials and methods}

Six taxa-1) snapdragon (Antirrbinum majus), 2) million bells (Calibrachoa xhybrida), 3) sweetpotato vine (Ipomoea batatas), 4) purple fountain grass (Pennisetum rubrum), 5) egyptian star-cluster (Pentas lanceolata), and 6) verbena
(Verbena xbybrida)-were used in this study with multiple cultivars of each (three cultivars of snapdragon, three cultivars of million bells, one cultivar of sweet-potato vine and purple fountain grass, two cultivars of egyptian star-cluster, and four cultivars of verbena). Snapdragon and million bells were obtained as rooted plugs and potted into 4 -inch-square pots and pinched back to half their height to encourage branching at potting. Sweet-potato vine and purple fountain grass were obtained as rooted plugs and potted into $115-\mathrm{mL}$ cells (six cells per pack and six packs per flat) using peatlite potting media in mid-May 2004. Egyptian star-cluster and verbena were grown from seed. Seeds were sown in late Feb. 2004 and transplanted into $50-\mathrm{mL}$ cells (four cells per pack and 12 packs per flat) using peatlite potting medium once large enough to be moved $(\approx 2$ weeks after germination). All plants were moved into a greenhouse at Pennsylvania State University (Penn State) after potting and watered by hand as needed (approximately daily). Fertilizer was applied at a rate of 200 ppm nitrogen from a $20 \mathrm{~N}-8.7 \mathrm{P}-$ 16.6K fertilizer.

Combinations were selected using SPSS (version 11.0; SPSS, Chicago). Five color harmonies $[1=$ monochromatic (violet), 2 = analogous (violet, red-violet, and blueviolet), 3 = direct complement (violet and yellow), $4=$ triad (violet, orange, and yellow-green), and $5=$ contrasting (violet, orange, and red)]; three container styles $(1=16$-inch-diameter round black plastic pot, $2=16$-inchdiameter round decorative foam planter, and $3=16$-inch-diameter round terra cotta); and three retail prices $(1=\$ 19.98,2=\$ 29.98$, and $3=\$ 39.98)$ were examined in this study. Using these factors, 45 total combinations were possible. An orthogonal design was created using OrthoPlan (version 10.1; SPSS) resulting in 25 nonrepeating combinations of color combination, container style, and retail price, a much more feasible number to ask participants to evaluate (Graham and Cable, 2001).

Planters were created using a predesigned style on 9 June 2004 using each of the six plant taxa. Planter design was chosen to allow survey participants to view it from one side for ease of display (Fig. 1). Plants 


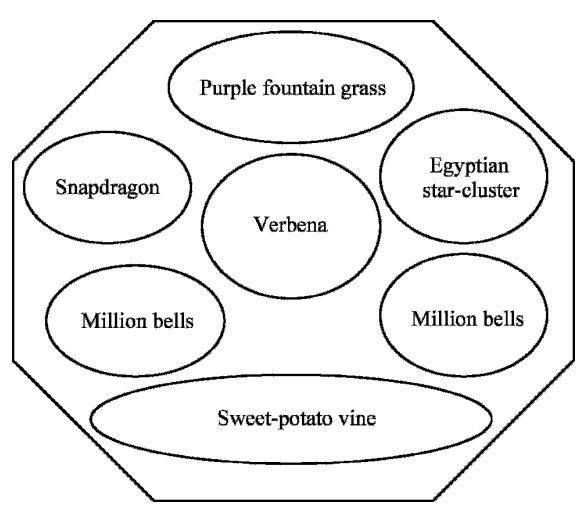

Fig. 1. Planter design for the annual planters used in a survey conducted at Grower, Retailer, and Master Gardener Field Days held at the Penn State Southeast Agricultural Research and Extension Center, Landisville, Pa.

were planted with the tallest toward the back of the planter with trailing plants toward the front. Each planter used the same design; however, plant varieties differed for each of the five color harmonies.

Price points were chosen based on those found in the State College, $\mathrm{Pa}$., and Landisville, Pa., areas during the Spring 2004 season-an average of $\$ 30$. A price below and above this average price was then chosen to determine what consumers would actually be willing to pay for the combinations in the study. Final retail prices used in the survey were based on suggested price barriers reported by Marciel (1989).

Mature planters were displayed 31 July 2004 at the Penn State Southeast Agricultural Research and Extension Center in Landisville, Pa., for a Penn State Master Gardeners event. Fifty-five Master Gardener consumers were self-selected to participate in a 10 -min survey to evaluate the containers looking at three factors: 1) color harmony, 2) container style, and 3) retail price. Participants were asked to rate each container on a 7 -point Likert scale ( $1=$ very unlikely; 7 = very likely) as to their likelihood of purchasing the containers.

Seventy-eight growers and 52 retailer/landscaper attendees participated in a related survey on 28 July and 4 Aug. 2004, respectively, to determine their likelihood to either produce or sell containers similar to the ones consumers evaluated and answered questions about their past annual planter sales and current horticultural products their company offered. Consumer participants also answered questions on past annual planter purchases and demographic questions, including age, gender, income, education, city, state, and household size. Data were analyzed using SPSS (version 13.0) using Pearson $\chi^{2}$ test $(P \leq 0.05)$.

\section{Results}

CONTAINER Garden CONSUMER DEMOGRAPHICS. A majority of consumer participants was female $(82.7 \%)$, had at least a Bachelor's degree $(59.3 \%)$, and lived in a household with at least one other adult (81.1\%) but without any children $(77.4 \%)$. Average participant age was 52 years. Slightly more than half of the participants $(60.0 \%)$ had an annual household income of at least $\$ 60,000$. Consumer participants had gardened for an average of 28.7 years with variations between 5 and 60 years. Most participants were trained as Penn State Master Gardeners $(87.3 \%)$ and had been certified Master Gardeners for an average of 4.8 years with ranges from 1 to 10 years.

Grower DEMOGRAPHICS. Mean grower participant age was 44 years with half of the participants $(50.0 \%)$ having at least a Bachelor's degree and slightly over half of participants $(57.9 \%)$ having either owner or head grower status within the company. Half of the participants $(50.0 \%)$ worked for a company with a gross annual income of less than $\$ 250,000$ and were in business for at least 25 years $(53.3 \%)$. Participants primarily worked for companies in southcentral Pennsylvania (82.3\%).

RETAIL AND LANDSCAPE DEMOGRAPHICS. Participant mean age was 41 years with approximately half of the participants $(44.7 \%)$ having at least a Bachelor's degree and approximately half of participants (56.5\%) having either owner or managerial status within the company. Half of the companies represented had a gross annual income less than $\$ 250,000$ (51.7\%). Most participants $(93.0 \%)$ were primarily located in south-central Pennsylvania with $43.9 \%$ serving Harrisburg, Pa., and 19.5\% serving Lancaster, Pa., as their primary market. Over half of the participants $(60.0 \%)$ served a market less than 30 miles from their business. Approximately half of the participants worked for a company that had been in business more than 15 years $(45.9 \%)$. Over half of the participants $(57.9 \%)$ indicated that over half of their business $(51.0 \%$ or higher) was landscape design/contracting, whereas the remaining participants $(42.1 \%)$ indicated the majority of their business was retail $(51.0 \%$ of the business or greater).

CONTAINer garden CONJOINT ANALYSIS. Of the 55 consumer participants, 49 ranked all 25 annual planter combinations and hence were used in the conjoint analysis. Price was found to be the most important factor in the decision to purchase, accounting for $43.1 \%$ of the decision, followed by color harmony (34.9\%) and container style $(22.0 \%)$. Utility values (a measure of how liked or disliked an attribute is by the survey participant) were also obtained for each level within retail price $(\$ 19.98, \$ 29.98$, and $\$ 39.98$ ), color harmony (monochromatic, analogous, direct complement, triad, and contrasting), and container style (black plastic pot, decorative foam container, and terra cotta container; Table 1). No significant difference was found between lowest (\$19.98) and middle (\$29.98) price; however, both were significantly more preferred than the highest price point (\$39.98). The most preferred color harmony was direct complement (consisting of violet and yellow flower colors), whereas triad (consisting of violet, orange, and yellowgreen) was preferred next by consumer participants. The contrasting (consisting of violet, red, and orange), analogous (consisting of violet, redviolet, and blue-violet), and monochromatic (consisting of tints, tones, and shades of violet) color harmonies were disliked by consumers. Significant differences were found between the direct complement and monochromatic color harmonies. No significant differences were found within container style.

Consumer gardening habits AND PLANTER PURCHASING BEHAVIOR. Few consumer participants had purchased annual planters in 2003 (13.2\%); most consumer participants $(86.8 \%)$ had not purchased annual planters in 2003 like those that they evaluated. Of those participants who did purchase planters, one-third bought them for use in their own home, one-third purchased them for 
Table 1. Conjoint analysis of annual planter color combination, container style, and retail price rated by consumers at a Master Gardener Field Day held 31 July 2004 at the Penn State Southeast Research and Extension Center in

Landisville, Pa.

\begin{tabular}{lcr}
\hline Factor & Avg importance (\%) & Utility $^{\mathrm{y}}$ \\
\hline Color combination & 34.86 & \\
Monochromatic & & $-0.1989 \mathrm{a}$ \\
Analogous & & $-0.1042 \mathrm{ab}$ \\
Direct complement & & $0.3011 \mathrm{~b}$ \\
Triad & & $0.0537 \mathrm{ab}$ \\
Contrasting & 22.02 & $-0.0516 \mathrm{ab}$ \\
Container style & & \\
16-inch-diameter black plastic & \\
16-inch-diameter decorative foam & \\
16-inch-diameter terra cotta & & $-0.1614 \mathrm{a}$ \\
Retail price & & $0.0070 \mathrm{a}$ \\
\$19.98 & 43.12 & $0.1544 \mathrm{a}$ \\
\$29.98 & & $0.2421 \mathrm{a}$ \\
\$39.98 & & $0.1342 \mathrm{a}$ \\
\hline
\end{tabular}

${ }^{\mathrm{z}}$ Higher value indicates greater importance.

${ }^{y} \mathrm{~A}$ more positive value is more desirable; letters within a factor represent significant differences at the $5 \%$ level. ${ }^{x} 1$ inch $=2.54 \mathrm{~cm}$

a gift, and one-third purchased planters for both purposes. The majority of participants who did not purchase annual planters cited that they prefer to make their own $(70.5 \%)$. When asked what they would pay on average for the containers on display, consumer participants responded with an average price of $\$ 25.68$ for the 16-inch-diameter round planters with responses ranging between $\$ 15$ and $\$ 40$. Households with at least one child were more likely to purchase annual planters $(33.3 \%)$ than those households without children (7.7\%; Table 2).

Consumer participants were asked whether they purchase books on creating and maintaining container gardens; those participants 55 years and younger were more likely to purchase such books $(92.9 \%)$ than those participants 56 years and older (62.5\%; Table 2).

RETAILER/LANDSCAPER PLANTER PREFERENCES AND PLANTER SALES BEHAVIOR. A majority of retail/ landscape participants in this study had never sold annual planters within their company $(75.0 \%)$. Of the participants whose companies had sold annual planters, $16.7 \%$ sold them before the 2004 growing season. Approximately half $(47.7 \%)$ of the retail/landscape participants indicated that they offer consumers point-ofpurchase material with directions as how to care for annual planters after the purchase. Retailer/landscape participants also indicated that they would charge their customers an average retail price of $\$ 31.67$ for a planter similar to the ones consumers rated in this survey with responses ranging from $\$ 7$ to $\$ 55$.

Retail/landscape participants whose company had gross annual sales greater than $\$ 250,000$ were more likely to consider plant form and growth habit when selecting annual planters to offer to their clientele (72.7\%) than were participants whose company had gross annual sales less than or equal to $\$ 250,000(23.1 \%$; Table 3 ).

GROWER PLANTER PREFERENCES AND PLANTER SALES BEHAVIOR. A majority of grower participants in this study had produced annual planters in the past $(75.0 \%)$ with slightly more than half of these respondents reporting that they produced planters before and during the 2004 growing season $(52.9 \%$ and $50.0 \%$, respectively). Over half of the grower participants (61.2\%) indicated that they attach pointof-purchase material to their planters to help consumers to properly care for the planter after purchase. Grower participants indicated that they would likely charge an average wholesale price of $\$ 21.68$, with a suggested average retail price of $\$ 36.83$, for 16-inch-diameter round planters like the ones consumers rated in this survey. Wholesale prices grower participants assigned to the planters ranged from $\$ 10$ and $\$ 50$, whereas the retail price ranged from $\$ 15$ to $\$ 75$.
Grower participants 45 years and older were more likely to attach pointof-purchase material to help educate consumers on proper annual planter care $(75.0 \%)$ than were those participants 44 years and younger (45.2; Table 4).

Grower participants who had an Associate's degree or less were more likely to consider price when creating annual planters $(73.5 \%)$ than those participants who had a Bachelor's degree or higher $(45.5 \%$; Table 4$)$. When participants were asked to identify colors that constituted a direct complement from four choices, grower participants with a Bachelor's degree or higher $(48.0 \%)$ were more able to choose correctly than participants with an Associate's degree or less (17.9\%; Table 4).

Grower participants who held owner or manager status within their company were more likely to consider sun and shade requirements of plants when creating annual planters (100.0\%) than participants who held any other position within the company, including head grower, assistant grower, or sales person $(78.6 \%$; Table 4).

Grower participants who worked in a company that had been in business for 24 years or less were more likely to consider drought tolerance when creating planters $(48.0 \%)$ than those participants who worked in a company that had been in business for 25 years or more (19.4\%; Table 4$)$.

\section{Discussion}

Price accounted for the greatest role in the consumer preference for planters tested in this study. For the container gardens, the least expensive price point $(\$ 19.98)$ was most preferred by consumer participants; however, there was no significant difference between the low price and the middle price point of $\$ 29.98$. Both the low and middle prices were significantly different from the high price point of $\$ 39.98$. It is apparent that consumers are looking for the greatest value for their money (Solomon and Stuart, 1997). Growers that sell planters at a lower price may be more likely to have their products appeal to consumers. Price, however, must meet the expenses of the grower's operation and should not be sacrificed. Consumers often indicate that they would be 


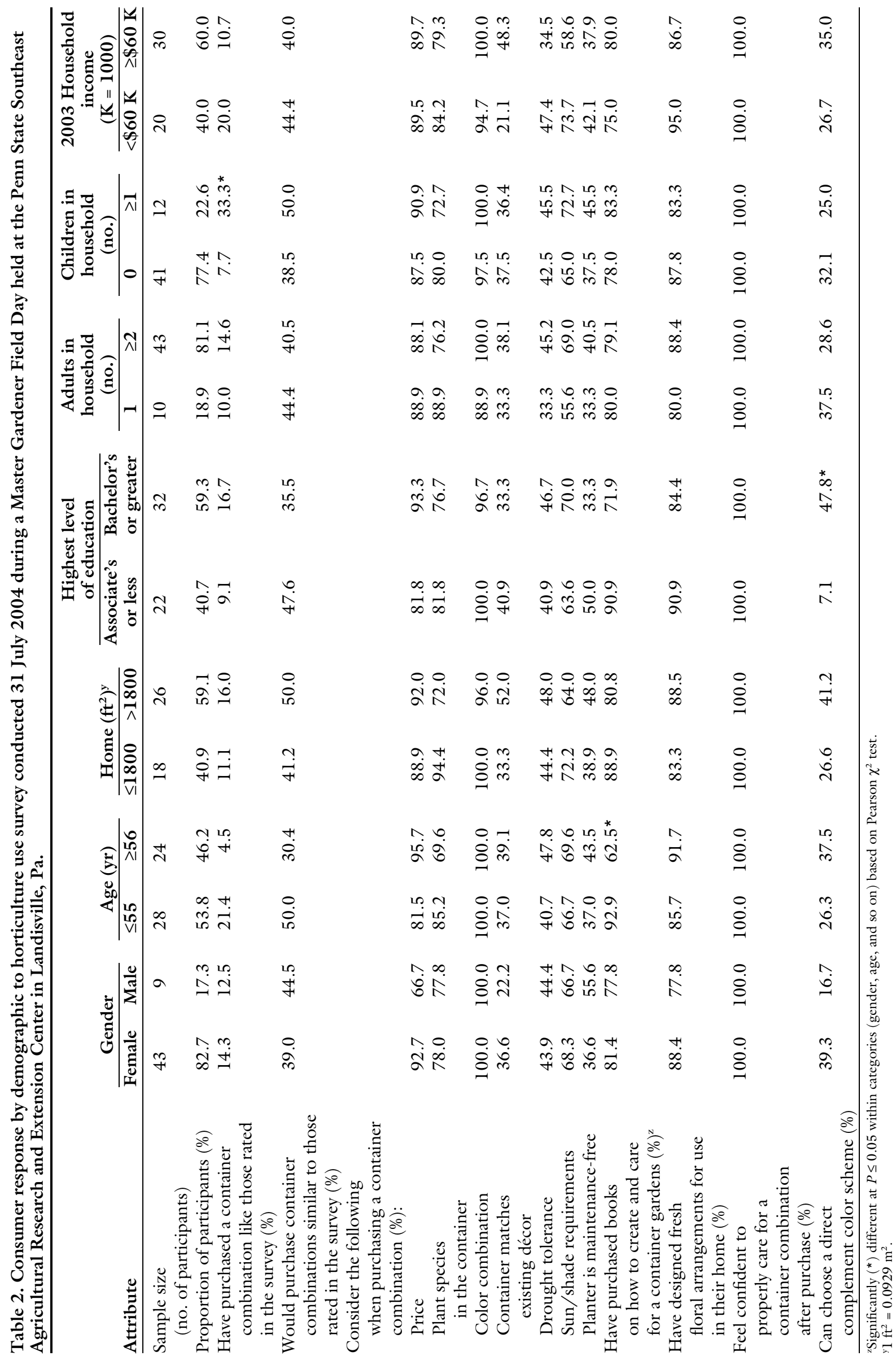


Table 3. Retailer response by demographic to horticulture use survey conducted 4 Aug. 2004 during the Retail and Landscape Field Day held at the Penn State Southeast Agricultural Research and Extension Center in Landisville, Pa.

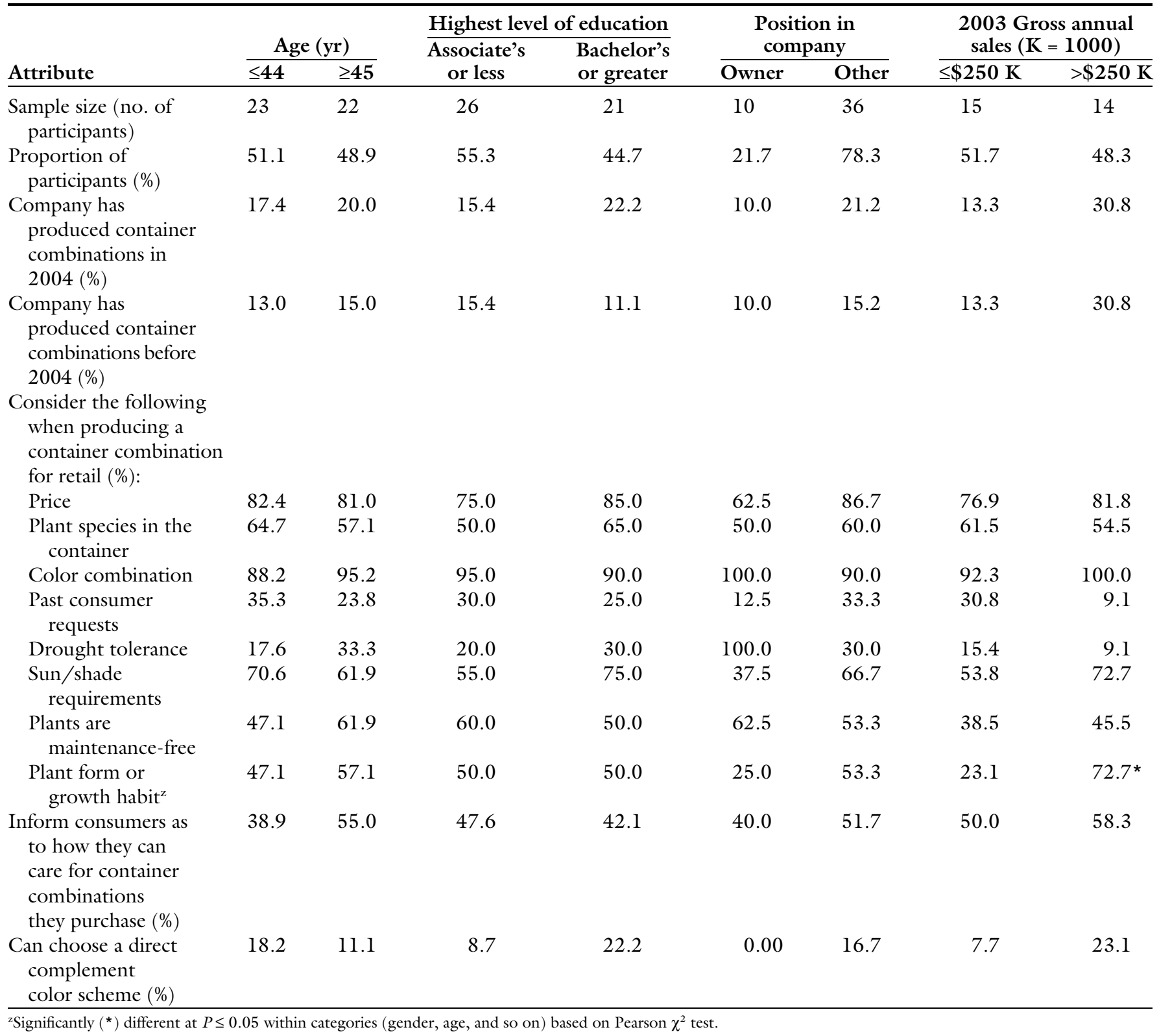

willing to pay a higher price for a product that incorporated added value (Konjoian, 2002). With limited time, consumers are more willing to spend additional money on an item that is finished and ready to use in their home without "assembly required" (Frowine, 2004).

For container gardens, color combination was the second most important factor in the decision to purchase an annual planter in the study $(34.9 \%)$. The most preferred color harmony was direct complement (consisting of violet and yellow flower colors), whereas triad (consisting of violet, orange, and yellow-green) was preferred next by consumer participants. The following color harmonies: contrasting (consisting of violet, red, and orange), analogous (consisting of violet, red-violet, and blueviolet), and monochromatic (consisting of tints, tones, and shades of violet) were disliked by consumers. Consumer participants seem to prefer those color harmonies that offer a greater variety of color within the container; however, it is unclear whether this preference stems from the actual preference for more color or the brightness of yellow in the direct complement combinations against the dominant sweet-potato vine and purple fountain grass. Based on these data, growers and retailers who are marketing annual planters to consumers may want to use color harmonies that provide the greatest display of color while still maintaining an attractive display.

For the container garden trial, the least important factor in the consumer participants' purchasing decision was container style $(22.0 \%)$. No significant difference was found among black plastic, decorative foam, or terra cotta containers within this study. One reason for this may be that the survey was conducted when the plants had reached maturity and little 


\section{Production and Marketing Reports}

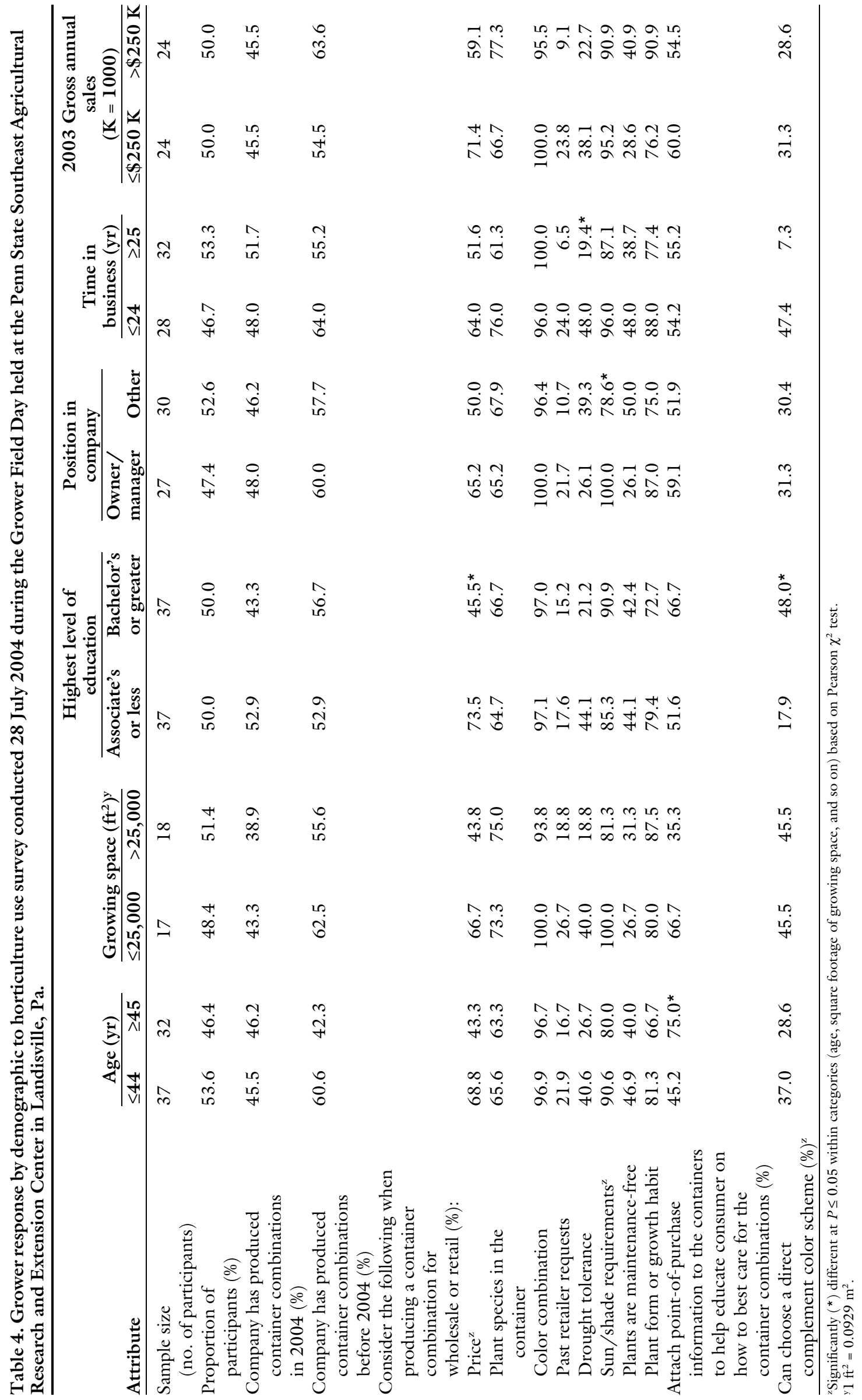


of the planter was in view. When selling fully mature planters, container style may not play as important a role as other factors to consumers because they are not directly noticeable when on display unless it is in stark contrast to the plant's leaf or flower color. For less mature planters, the container may play a greater role. With gift baskets, the container often plays a primary role in setting the price. If a consumer perceives the value of the container to be greater than comparable products, they are often willing to pay more for the item (Garrett, 2004). This principle may also be applied to container gardens. A large part of the overall appeal of container gardens is the variety of container options available. Additionally, consumers are looking for containers that are not the standard plastic used throughout the industry (Frowine, 2004). Decorative containers can be incorporated as a valueadded component to annual planters to help increase the perceived value of the package and allow growers and retailers to command a higher price.

C ON S U M ER P L A N T E R PURCHASING BEHAVIOR. Few (13.2\%) of the consumer participants purchased annual planters during 2003. The majority of those who did not purchase planters cited that they prefer to create their own. Because most participants had been trained as a Penn State Master Gardener, these participants may be more likely to design and plant their own annual planters than consumers without any Master Gardener training. Growers and retailers can still target this segment of consumers by marketing a product that will appeal to these experienced and knowledgeable consumers. For example, options could include l) offering an instruction sheet that can be sold with annual plants that consumers can purchase, take home, and plant in a container of their choice; or 2) offering a package that allows consumers to choose a container from an available selection, then choose a specified number of plants that are color-coordinated and grow well together to plant in the container when they return home. These types of packages offer consumers who may not purchase a preplanted container a variation of a value-added product.

Households with children were found to be more likely to purchase annual planters than those households without children. According to the National Gardening Association (2003), households nationwide without children were more likely to purchase container gardens. Over half of the participants in this survey $(56.4 \%)$ indicated that they prefer to make their own annual planters. Because our audience consisted of mostly gardening-savvy consumers, it may not be a representative sample of the nationwide average gardening audience. Although no data were found to support this, it is possible that consumers with children use container gardens to save time but still want to add decoration to their home.

Participants aged 55 years and younger were more likely to purchase books on container gardens. This age group may have less gardening experience than those participants 56 years of age and older and therefore may be more inclined to seek information from professional sources. Additionally, with increasing popularity of container gardening, consumers may be using how-to books for ideas when creating their own container gardens.

RETAILER/LANDSCAPER PLANTER SALES BEHAVIOR. The majority of retail/landscape participants in this study had never sold annual planters within their company. With the rapidly growing popularity of container gardens, this is a product that retailers could easily offer their customers to increase sales and, ultimately, revenue. Retail sales of container gardens more than doubled between 1997 and 2002 and is one of the fastest growing gardening categories in the United States (National Gardening Association, 2003). One of the top five responses that consumers reported, when asked what they would like to see improved in garden centers, was a suggestion that retailers increase their selection of unique and specialty items (American Nursery and Landscape Association, 2000). The Society of American Florists (2004) reported trends for floral outlets. Mass merchandisers such as home improvement and grocery stores were showing a steady increase in market share, whereas traditional floral outlets such as garden centers were declining in their market share. These unique products that consumers are looking for, which could include container gardens, may be useful to retailers to regain their documented lost market share.

Point-of-purchase (POP) material is an important method to attract consumers to retail outlets. Recently, there has been an increasing tendency for consumers to request product information for the items that they consider purchasing (Solomon and Stuart, 1997). Simply incorporating signage describing the products available can increase the sales of the product significantly. A study performed on in-store signage for soft drinks showed an increase of sale up to $445 \%$ (Solomon and Stuart, 1997). This particular example may be the extreme but demonstrates the ability of signage to attract consumer attention and encourage purchases. In this study, roughly half of the retail participants said that they use POP material for care of container gardens. Incorporating signage describing container garden care can be used as a value-added component and may increase the perceived value of the annual planters, thereby enticing consumers to purchase the product over other choices available.

Retail/landscape participants working for companies with gross annual sales greater than $\$ 250,000$ were more likely to consider growth habit and plant form when choosing an annual planter to sell to their customers than their counterparts. It is unclear as to why retailers with higher gross annual incomes are more likely to consider growth habit or plant form; perhaps there is a tendency for consumers to choose annual planters that have a defined form and texture pattern. Retailers that create containers that include these criteria may see increased sales from their clientele, who have a preference for this product. Additional studies need to be conducted to focus on the difference between the two groups and determine what benefit, if any, there could be if annual planters are created based on form and habit.

GROWER PLANTER SALES BEHAVIOR. The majority of grower participants in this study had sold annual planters before 2004. According to the data, grower participants appear to recognize the potential of container gardens in increasing market share as a result of their increasing popularity. In addition, over half of the grower participants attach POP 
material to the annual planters that they create. Growers, too, must create products that will appeal to end-users and by incorporating a value-added component such as POP material, they can command a higher price. Growers 45 years of age and older were found to be more likely to attach POP material than growers less than 45 years of age. More mature growers may have more experience with sales and have a better understanding of what a retailer or consumer desires when purchasing an annual planter. Other reasons may be found as to why growers aged 45 years and older use POP material more often than their counterparts; however, there would need to be more specific research performed to remove speculation.

When creating a planter, grower participants with an Associate's degree or less were found to be less likely to consider price when creating an annual planter than those with a Bachelor's degree or higher. Additionally, grower participants who held owner or managerial status within the company were more likely to consider sun and shade requirements than those participants who held any other position within the company. Education often plays an important role in determining the position a person can achieve within a company. With a higher education level, an employee will often hold a position with greater responsibility such as manager or owner. These employees may be more involved in wholesale and retail sales and are more likely to make decisions regarding annual planter composition and retail price. Understanding that a consumer desires the best price possible, consumer preferences involving annual planters can affect what type of planters a grower will produce.

Finally, grower participants who worked for a company in business for 24 years or less were more likely to consider drought tolerance when creating an annual planter than participants who worked for a company in business for 25 years or more. It is unclear as to the reasoning behind this conclusion and again, more work would need to be done to determine the possible explanations for this point.

In summary, consumers make the ultimate decision as to what is produced for sale. Both retailers and, to a lesser extent, growers follow consumer desires when marketing annual planters. For consumers, retail price plays an important role in determining whether to purchase an annual planter. This is expected because there is limited discretionary income available and retailers and growers in the horticulture industry are competing with all other industries to capture as large a portion of that discretionary income as possible. By determining what consumers are actually looking for, retailers and growers can hone their products to directly fulfill the need instead of creating products on a hit or miss basis. Based on this study, we can see that consumers prefer containers that use a large variety of color within the container for maximum display. Additionally, although consumers may prefer the lowest price, retailers and growers may find their consumers are willing to pay more for containers if they deem them to be of greater worth than traditional product offerings. Finally, with regard to container style, consumers preferred containers that were more decorative than black or green plastic pots, although not significantly.

Retailers and growers who market annual planters should focus on the consumer preferences for more color and decorative containers with less emphasis on price. In addition, consumer interest in form and texture in the planter may be increasing.

\section{Literature cited}

American Nursery and Landscape Association. 2000. Exclusive insights into the gardening consumer: 2000 grapevine survey. American Nursery and Landscape Assn., Washington, D.C.

Behe, B., R. Nelson, S. Barton, C. Hall, C.D. Safley, and S. Turner. 1999. Consumer preference for geranium flower color, leaf variegation, and price. HortScience 34:740-742.

Butterfield, B. 2003. National Gardening Survey 2002. National Gardening Assn., South Burlington, Vt.

Carlson, W. 2004. Don't produce a commodity. Greenhouse Grower 22:20-23.

Coltrain, D., D. Barton, and M. Boland. 2000. Value added: Opportunities and strategies. 14 Nov. 2006. <http://www. agecon.ksu.edu/accc/kcdc/PDF\%20Files/ VALADD10\%202col.pdf $>$.

Frank, C.A., R.G. Nelson, E.H. Simonne, B.K. Behe, and A.H. Simonne. 2001. Consumer preference for color, price and vitamin $\mathrm{C}$ content of bell peppers. HortScience 36:795-800.

Frowine, S.A. 2004. More sophisticated. Time-crunched. Less experienced. Meet the garden consumer. Garden Ctr. Merchandising Mgt. 10:40-41.

Garrett, E.H. 2004. Gift baskets stir sales. Produce Business 20:91-94.

Graham, M.E. and D.M. Cable. 2001. Consideration of the incomplete block design for policy-capturing research. Organ. Res. Methods 4:26-45.

Hillier, M. 2000. Flowers. Dorling Kindersley, N.Y.

Jett, J.H. 2005. Container gardening. 15 June 2005. <http://www.wvu.edu/ $\sim$ agexten/hortcult/homegard/ cntanegrd.htm>.

Kelley, K.M., B.K. Behe, J.A. Biernbaum, and K.L. Poff. 2001. Consumer preference for edible-flower color, container size and price. HortScience 36:801-804.

Konjoian, P. 2002. Is floriculture headed toward commodity marketing? Ohio Florists’ Assn. Bul. 874.

Manalo, A.B. 1990. Assessing the importance of apple attributes: An agricultural application of conjoint analysis. Northeastern J. Agr. Resource Economics 19:118-124.

Marciel, R. 1989. Pricing your garden center products. Ohio Florists' Assn. Bul. 714 .

Miller, C. 2001. Surveys reveal container gardening popularity. 18 Feb. 2004. <http://www.greenbeam.com/features/ tour021901.stm>.

Miller, C. 2004. Trends 2005: A new hope is on the horizon. Garden Ctr. Merchandising Mgt. 10:42-45.

National Gardening Association. 2003. National Gardening Survey 2002. National Gardening Assn., South Burlington, Vt.

Society of American Florists. 2004. Floral trend tracker Spring 2004. 13 Nov. 2006. <http://www.safnow.org/ content/category/8/117/227/>.

Solomon, M.R. and E.W. Stuart. 1997. Marketing: Real people, real choices. Prentice Hall, Upper Saddle River, N.J.

SPSS, Inc. 1997. SPSS conjoint 8.0. SPSS, Inc., Chicago.

SPSS, Inc. 2001. SPSS training: Advanced market research. SPSS, Inc., Chicago.

Wolnick, D.J. 1983. Consumer preference studies with zonal geraniums. Florists' Rev. 173:31-33. 